\title{
Analysis of the Mode of Express Delivery to Countryside
}

\author{
Yuan Shao, Min Yang, Ya-juan Wang \\ College of Management \\ Wuhan University of Science and Technology \\ Wuhan, China \\ shaoyuan@wust.edu.cn, wangyajuan@wust.edu.cn
}

\begin{abstract}
This paper uses comparative analysis approach to analyze the problems and operation modes of express delivery to the countryside, which considers that China's "The Twelfth Five-Year Plan" and the development of e-commerce have promoted the development of express delivery to the countryside, but on account of the decentralization of rural distribution and the particularity of the rural market, express delivery enterprises are still faced with high cost, poor distribution, unbalanced delivery obstacles in expanding the rural market. It is imperative to complete the logistics infrastructure in rural area and solve the problems of rural market development. This paper conducts a comprehensive elaboration including the development status, the agents, the exposed difficulties and solutions of express delivery to the countryside, and looks forward to the research in future.
\end{abstract}

Keywords-comparative analysis approach; operation modes; rural market

\section{INTRODUCTION}

Express delivery is a door to door logistics activity, associated with the production, currency, consumption, investment, financial and other fields, is a special logistics form. The improvement of the transportation, information and other infrastructure, the development of e-commerce (driven), the situation of the second-tier and third-tier cities tending to saturation, have prompted e-commerce enterprises to explore the potential of online shopping in towns, thus China's express delivery finds a new direction of development: exploring the vast rural township market.

In recent years, the focus of researches on rural markets at home and abroad is the relationship between the e-commerce development and rural markets, which generally focus on the rural markets which is considered as the next opportunity of ecommerce, and less concern about the currency field of ecommerce, the media of e-commerce to the countryside: the relationship between express industry and rural markets. The significance of the paper has three aspects: First, analyze the agent of China's express delivery enterprises exploring the rural market from the subject and object aspects. Second, utilize the urban and rural comparative approach to study the particularity of the rural market compared to the city market, and analyze the advantages and disadvantages of the obstacles during express enterprises to the countryside and the various operation modes through the comparison of same industry's different operation mode. Third, discuss the development strategy of express delivery enterprises exploring the countryside from the perspective of promoting express enterprises to better explore the rural market.

\section{PRESENT SitUATION OF INTERNAL RESEARCH}

At present, China's research on the express delivery business focuses on the express industry status, express delivery industry market structure, enterprise competitiveness. Zhang Hongbin (2006) has introduced the characteristics of the express industry in detail in the "China Express Market Development Research Report", which discriminated the structure of the express market, international express delivery; internal (remote) express delivery and city express, and analyzed their respective development policies ${ }^{[1]}$. Wei Guangxing (2010) have focused on the competitiveness of express delivery enterprises, used the existing literature research results for reference to set up market size, service level, price level, safety level, network level and value-added services competitiveness index system, in which he regarded the market size, service level and the network level as instrumental factors in determining the competitiveness of express delivery ${ }^{[2]}$. Geng Songtao (2004), conducted the research respectively, from the scale economy barriers, the necessary capital barriers, product differentiation barriers and barriers to policies a regulations and other aspects of China's express market's barriers when entering ${ }^{[3]}$, pointed out that China's internal express delivery enterprises must strengthen the network system. However, the focus of the research above is on the whole system of the express industry, not focusing on the rural market. Therefore, this paper draws lessons from the research summary of the express industry above, studies the status of express delivery to the countryside, the rural markets' structure of express delivery enterprises and how to enhance the competitiveness of express delivery enterprises in exploring the rural market.

\section{THE AGENT OF EXPRESS DELIVERY TO COUNTRYSIDE}

The development of express enterprises in rural markets is under the political and economical and some other macroscopically conditions, driven by a number of specific factors, which can be divided into the extrinsic factor of express delivery industry to develop the rural market and the direct factor of express delivery enterprises to explore the rural markets as an independent individual. 
A. The Extrinsic Factor of Express Delivery Enterprises Exploring the Rural Market

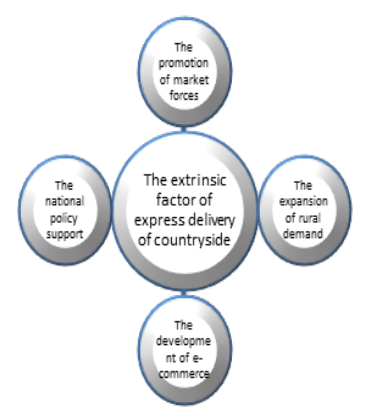

Fig. 1. The Extrinsic Factor of Express Delivery Enterprises Exploring the Rural Market

1) The promotion of market forces is the basic factor in the development of rural market in express delivery enterprises.

The promotion of market forces performs mainly in two aspects, the increase of business volume and the enhance of express industry competition:

a) The increase in express delivery volume: Express delivery enterprises are an important part of the modern service industry, associated with the production of circulation, consumption, investment and financial and other fields [4], which plays an irreplaceable basic role in the restructuring of national economy. In recent years, China's express delivery enterprises lead sustained rapid development. According to the State Post Bureau statistics, in 2014, the volume of express business (totaled 13.96 billion), has a year-on-year growth of 51.9\%; the business income totaled 2045.4 billion yuan, with year-on-year growth of $41.9 \%$, so the express delivery enterprises have a wide market prospect ${ }^{[5]}$.

b) The enhance of the express delivery enterprises competition: the share of the express market by respective enterprises tends towards stability, second-tier and third-tier cities tend to saturation, and because of the intense express companies competition, many delivery companies have changed the direction of development from metropolis to rural areas in order to expand market profits.

2) The expansion of rural demand is the key factor in the development of rural market in express delivery enterprises.

The key factor of express delivery to the countryside is the expansion of rural markets, which is specifically performed in the following three areas:

a) Rural netizens account for $28 \%$ of the total netizens, which have huge consumer demand. For example, in 2013, the scale of rural Internet users has $13.5 \%$ growth rate, higher than the growth rate of $8 \%$ of cities and towns. In 2014, rural online shopping market totaled more than 180 billion Yuan ${ }^{[6]}$, thus there's an urgent need to explore the value of the rural market.

b) The development of urban and rural unification, the increase in population mobility, and the improvement of township road construction provide the possibility for the rural agricultural and sideline products, so that farmers would really benefit from the e-commerce platform.

c) The rural network infrastructure continues to be improved, the popularity of information technology grows and logistics infrastructure and logistics services continue to be improved, which makes the focus of social logistics services turn to rural areas ${ }^{[7]}$.

3) The development of e-commerce is the incentive of express delivery enterprises to explore the rural markets.

a) The development of e-commerce appears two new features: a. price war cooled down, logistics competition warmed. b. the focus on large and medium-sized cities turned to the vast rural areas, these two features are the direct cause of express delivery to the countryside.

b) E-commerce enterprises and express delivery enterprises strengthen further cooperation, utilize the mature logistics system of express business and the complete distribution system, thus express delivery enterprises can strive for control power of the supply chain, and conducts strong cooperation with e-commerce enterprises to improve the e-commerce platform for the convenience of rural residents' online shopping ${ }^{[8]}$.

4) The national policy support is the guarantee of the development of the express delivery enterprises in the rural market.

In 2014, the document No.1 of the central authorities involved in the express delivery enterprises for the first time, requiring to improve rural logistics system, accelerate the development of agricultural commodities' modern logistics facilities in major producing areas, and complete the coldstorage chain logistics system of fresh agricultural products. The State Administration for Industry and Commerce (SAIC) has promulgated views on promoting the improvement of the circulation industry, which supported the extension of the network commodity trading platform to rural development to improve the efficiency of circulation in rural areas and facilitated the farmers' lives ${ }^{[9]}$. In addition, the government has promulgated some documents such as "a number of opinions on the promotion of information consumption to expand domestic demand" and others which have strongly supported the process of express delivery to the countryside.

\section{B. The Direct Factor of Exploring the Rural Market (take SF Express for example)}

SF Express conducted the countryside model, there are three direct reasons:

Second-tier and third-tier cities express market tend to saturation, express competition in the industry is intense, the price war warm, express delivery companies began to compete for rural markets in order to seize the initiative, and they set off a craze in express delivery to the countryside. SF Express had to conform to the trend of development to turn from large cities to rural markets in order to obtain development advantages. 
In express delivery to the countryside business, EMS and the ST Express, YT Express, ZT Express, Best Express and YD Express have arranged the layout of the rural market earlier compared with SF Express, and have a certain coverage basis, only when SF Express step up the layout of the rural market can it gain the market share ${ }^{[10]}$.

The establishment of the township network is the result of the company's comprehensive consideration. In terms of the demand, the company's customer service will also receive business advice, consumers will ask whether there are the company's network or not nearby; In addition, the business density and geographical environment of rural network will be measured by the company ${ }^{[11]}$.

\section{The CuRRENT Situation of EXPRESS Delivery to THE COUNTRYSIDE}

\section{A. The Operation Mode Analysis of Express Delivery to the Countryside}

1) The distribution mode analysis of express delivery to the countryside
There are three main methods in express delivery to the countryside:

a) The first method is to establish service networks by express enterprises, and extend down to achieve regional coverage through the service network. For example, SF Express adopts the regular chain mode, exclusively agents and encourages employees to return home to found business, and operates normative can practice SF standard to ensure the service quality of SF Express, but the operating costs and the service prices are relatively high.

b) The second method is to entrust to other companies' network to become the agent of its service, extend the service chain to achieve final delivery. Some express delivery enterprises cooperate together in order to reduce operating costs, establish township-level service sites, such as ZTO, YTO, STO Express and CCES established associated company.

c) The third method is the express delivery enterprises conducting collecting and forwarding business relied on the township level convenience store supermarkets, such as Best Express and Daily Express, which adopted the model and reduced the facilities investment in the layout points.

TABLE I. COMPARISON OF VARIOUS DISTRIBUTION MODES OF EXPRESS DELIVERY TO COUNTRYSIDE

\begin{tabular}{l|l|l|l|l|l}
\hline $\begin{array}{c}\text { distribution } \\
\text { mode }\end{array}$ & $\begin{array}{c}\text { distribution } \\
\text { mode }\end{array}$ & $\begin{array}{l}\text { Management } \\
\text { mode }\end{array}$ & $\begin{array}{l}\text { Service } \\
\text { quality }\end{array}$ & $\begin{array}{l}\text { Operating } \\
\text { cost }\end{array}$ & $\begin{array}{l}\text { Service } \\
\text { Price }\end{array}$ \\
\hline $\begin{array}{l}\text { Self-built } \\
\text { network } \\
\text { sf-express }\end{array}$ & sf-express & $\begin{array}{l}\text { unified } \\
\text { management }\end{array}$ & $\begin{array}{l}\text { Practice standard of SF, Aging fast, } \\
\text { high level } \\
\text { of services }\end{array}$ & higher investments & $\begin{array}{l}\text { National unified } \\
\text { price, fixed price }\end{array}$ \\
\hline joining mode & Yunda Express & $\begin{array}{l}\text { decentralized } \\
\text { management }\end{array}$ & $\begin{array}{l}\text { Poor service quality and } \\
\text { poor sense of responsibility }\end{array}$ & $\begin{array}{l}\text { low investment } \\
\text { cost }\end{array}$ & $\begin{array}{l}\text { Service prices are } \\
\text { not unified }\end{array}$ \\
\hline $\begin{array}{l}\text { Cooperate with } \\
\text { commercial } \\
\begin{array}{l}\text { agency } \\
\text { supermarkets }\end{array}\end{array}$ & TTK Express & $\begin{array}{l}\text { Rely on the } \\
\text { third party } \\
\text { construction is low }\end{array}$ & $\begin{array}{l}\text { The quality of service is } \\
\text { difficult to guarantee } \\
\text { relatively low }\end{array}$ & \\
\hline
\end{tabular}

2) The cost analysis of express delivery to the countryside

a) The cost of express delivery enterprise to the countryside is the content that must be analyzed deeply, and the cost mainly includes the fundamental facilities of the business outlets, such as distribution tools, computers, office etc., and staff salaries, management costs, operating costs and so on. The total investment costs of township-level service site construction are lower compared with cities', due to the lower facade rent, and the urban and township wage level gap.

b) Compared with the urban network sites, urban express quantity is larger, and can partly offset the investment of operating cost. In addition, urban residential houses are concentrative, and the concentration of express dispatch can save labor costs, while township-level delivery can not make up for operating costs because of less delivery quantity and higher operating costs.

\section{B. The Development of Express Delivery to the Countryside Status}

1) The increase of enterprises to countryside

Owing to the enterprises development strategy and national strategy to create a resonance, big enterprises such as the Post,
Ma Yun signed a strategic cooperation agreement with China Post to obtain rural network resources, JD Mall set up "Pioneer Station" in regions and counties, Ali's expanding method is the Rookie network together with logistics RRS. Logistics SF, ST Express, YT Express, ZT Express, Best Express and YD Express take a variety of expanding modes to explore the rural market. Every express delivery companies are fully aware of the huge potential of the rural market and start to open the countryside model.

\section{2) The wide range of rural market development}

Last year, 50,000 rural network were established, which covers $48 \%$ of the township in the whole country, and delivery parcel quantity reached 2 billion, leading the industrial sales to the countryside reaching 160 billion Yuan, which is a great achievement. At the same time, agricultural and sideline products have begun to enter.

\section{3) Significant economic benefits}

On the one hand, express delivery to the countryside unclogs the urban and rural markets precipitates the interaction between urban and rural consumption, and through this platform, many rural agricultural sideline products can also enter the city. At present, some of the rural featured products, whether it is Hubei lotus root, Shanxi apple, Guangxi Baise 
mango, Shandong cherry or Guangdong lychee, can be enjoyed by the majority of urban residents. On the other hand, the residents can also enjoy the convenience of the express delivery to the countryside, thus residents do not have to consider the distance to the required items, just a little click on the Internet instead and express companies would deliver soon. It makes great significance in the promotion of consumption and driving farmers to achieve prosperity, so that the farmers under the e-commerce system would benefit actually.

\section{The Bottleneck of Express Delivery to Countryside Status}

1) Rural infrastructure limits, network layout is difficult with high cost

Rural areas need huge capital investment to increase the logistics and distribution points, because the rural logistics system and the infrastructure are not complete, rural logistics coverage is small, and for the lack of business support in initial stage, the express delivery enterprises can only get a small amount of profits. In addition, due to the decentralization of the population in rural areas, transportation facilities are not perfect, express services are faced with the disadvantages of more sites, wide coverage, long line, the unit transport costs and high cost of delivery make express delivery cost much higher than the city and developed areas.

2) The residents' online shopping awareness is not strong, which limits the contribution to the express market

Due to the limited level of development of rural and township areas, the low income per capita, there is not much room for business growth in a short period of time. In addition, there are many young adults migrant workers in Midwest less developed areas, the residents left behind have weak awareness of online shopping. Their devotion to the express market is low.

3) The unbalance of express transmission and distribution and clear low and peak season

Because the young adults become migrant workers, people who consume outside are mainly to purchase the necessary items for the family and friends, therefore the express delivery volume is less and only have the demand for receiving delivery, thus the township-level network is difficult to receive profits from the distribution of express mail. And delivering is unbalanced; they can only receive the end profits of the distribution.

Before the Spring Festival, due to a large number of young people returning to home, the service network express mail collection and dispatch volume has greatly improved, the service network traffic is significantly higher than usual, showing a relatively boom season. In addition, logistics and distribution demand in the rural markets also has entered peak season. In addition, rural market is a production area. With the time difference of the sowing and harvest season of agricultural and sideline products, logistics and distribution needs also have relatively low and peak season.

4) Villagers generally pick up by their own, collecting is not convenient

Because the rural layout is dispersed, the express network staff is limited, the rural house number is not clear and the express mail receipt address is not clear, express mails are mainly backlogged in the county distribution network, thus many county-level delivery speed is generally slower than the city. Many county towns are provided with home delivery service, while villagers have to pick and deliver by themselves in township-level, which have an impact on the demand of villagers to some extent.

\section{THE PROPOSALS AND SOLUTIONS TO EXPRESS DELIVERY TO THE COUNTRYSIDE}

\section{A. The Solutions to the Express Delivery Enterprises Level}

\section{1) Promoting commonality distribution}

In the county network, express delivery enterprises conduct township-level distribution and build information platform together, with the ST Express, YT Express, ZT Express, Best Express and YD Express or postal and other co-distribution. When the business volume is less, they could choose other express to deliver. On one hand, it can reduce the distribution of unloaded ratio, save distribution costs of the last kilometer, save resources, and then the resources will be used to subsidize the cost of township network operation. On the other hand, for the reason that the township is dispersive, many county express mails are backlogged, only through cooperation can they improve effectiveness to meet the consumers' urgent express need.

2) Learning from each other and having complementary advantages

a) To take cooperation or franchise mode, first, the express delivery enterprises should learn from the SF service mode, which leads urban and rural service standardization, standard integration, improving service standards, improving the distribution effectiveness and the integrality of the express mails, but the enterprises could not ignore the quality of rural services while taking this kind of mode. Second, we can learn from the mode of encouraging employees to start their own business, and support employees to return home to start business. On one hand, it can reduce the training costs of external recruitment costs; on the other hand, employees would understand more about the company's philosophy, thus their corporate responsibility can improve the service level, and it can avoid all kinds of disadvantages due to the inconformity of business philosophy and service concept, and the lack of complete operation training.

b) To take the regular chain mode, the express delivery enterprises can act according to circumstances. Divide according to the scale of township-level district and population size, and the enterprises can adjust the operation mode appropriately. If the township population is scarce, enterprises can appropriately take cooperation with other express delivery or supermarkets and other convenient service.

3) Taking the price measures to increase the amount of express delivery

Township-level network usually serves for surrounding villages, due to the economic development difference between the township and the surrounding villages, township-level network delivery volume mostly belong to the county residents, 
and the surrounding village express delivery volume is relatively small, which increases the receive and delivery express mail unbalance further. Based on their respective business volume, express delivery network utilizes price discounts to appeal residents' delivery demand, particularly; it can promote cooperation with the online shopkeepers to promote business volume.

\section{4) Enterprises strengthening quality management}

The key to express delivery to the countryside is the last one kilometer distribution, the quality of the end of the express delivery is difficult to guarantee because the many distribution links, long distance, increased quantity of work, relatively weak supervision of the enterprises in remote areas. In addition, express delivery enterprises mostly cooperate with supermarkets, convenience stores and rural integrated service stations etc., thus the number of transit is more than before and it's easy to lead to express damage and loss. In order to seize the rural market, express delivery enterprises must strengthen the quality of supervision, conduct operation staff training and increase financial investment.

\section{B. The Guidance Measure on National Level}

\section{1) Strengthening guidance on policy level}

We should strongly support the express delivery enterprises to set up more business network (terminal network) in the county level, and qualified areas can extend to the township and rural areas, thus farmers can also get express service at home. Meanwhile, we should enhance the network management to improve the terminal service level comprehensively, and support and promote the investment of third-party enterprises in terminal service fields, conduct express delivery to the countryside and downwards, and guide the direction for the construction of terminal network.

\section{2) National infrastructure improvement}

The state accelerates the improvement of rural circulation network, promotes large-scale distribution enterprises to expend operation network towards countryside, and speeds up the construction of a number of township business center. In addition, the state accelerates the improvement of agricultural products circulation facilities, constructs agricultural products cold-storage chain system, and sets up agricultural products logistics system.

\section{3) Setting up information platform to strengthen the} informatization construction

Informatization can not only reduce the cost of logistics, but also improve the efficiency of express delivery services, and through the analysis and integration of express information, we can take the mode of same city, same car and different service objects based on the difference of township network to save the distribution cost on township-level network to the best advantage. In addition, it can enhance the abutment between consumer and express service. Therefore, the government can set up information platform in the process of express delivery to the countryside to strengthen the information construction.

\section{SUMMARY}

The Mode of Express Delivery to Countryside is developed rapidly with the development of electronic commerce.is based on the express enterprise's own development strategy and the new development model is carried out by the jointly promotion of the enterprise strategy and national strategy. Because the rural express market is imperfect and has imperfect infrastructure, people live rather separately, etc. express delivery to the countryside faces many problems. For example, express delivery enterprises have high input cost, long recovery time, weak existing profits, etc. Some enterprises still take the wait-and-see attitude towards countryside. But for express delivery companies, since the electronic commerce is the focus of competition in each big enterprise, to win out in the fierce competition, we must increase the network construction in central and western regions, especially in the villages and towns market, so as to occupy the rural market and fully tap the potential of rural market.

This article points out the constraining bottleneck of express delivery to the countryside by analyzing the mode of express to the countryside and its status quo, and puts forward the solving measures, so as to further promote the express delivery enterprises to fully develop rural market and take the last one kilometer, and at the same time help farmers truly enjoy the convenience brought by express to the countryside under the boom of e-commerce development.

\section{ACKNOWLEDGMENT}

This research was financially supported by the National Science Foundation of China (71501147), cultivation plan project for young scholar at Wuhan University of Science and Technology (250089) and teaching research project at Wuhan University of science and technology (2015X037).

\section{REFERENCES}

[1] Y.M. Zhao, H.B. Zhang. Research report on the development of Chinese express market [J]. Economic research reference, 2006, 34 (1)

[2] G.X. Wei. Research on the competitiveness of express companies based on information entropy and grey correlation method [J]. Technology management research, 2010, 07 (4): 24-25

[3] Anonymous. Express concept. http://baike.haosou.com/doc/50145415239951.html, 2015-5-25

[4] S.T. Geng, Z.H. Jiang. Analysis on the entry barriers of express delivery market [J]. Logistics technology and application, 2004, 16 (3) : $12 \sim 15$

[5] J.S. Ma. Peasant demand to promote "express delivery to the countryside" project [N]. People's Daily, 2015-2-16 (10).

[6] Y.F. Lu. Transform SF.The new economy, 201506 (6) : $14 \sim 15$

[7] W. Ni. The battle of e-commerce logistics [J]. Logistics age, 2014, 317 (8) : 24-25

[8] X.F. Hou. Analysis on the Situation of China's E-Commerce Logistics[J]. Advance Materials Research, 2014: 3750-3753

[9] Anonymous. SF encourages employees to go home and start their own business. Netease technology, 2014-08-07 (10)

[10] Wang guanghui, Li qingjin. The service innovation of logistics industry [J]. China logistics and procurement, 2000, 16 (7) : $19 \sim 20$

[11] Li sha. Research on collaborative development of e-commerce and express logistics [D]. Thesis of bachelor's degree in Beijing university of posts and telecommunications 